\title{
An Inventory Model for Deteriorating Items With Exponential Declining Demand and Return
}

\author{
Fadli Fadli $^{1 *}$, Sudradjat Sudradjat ${ }^{2}$, E. Lesmana ${ }^{2}$ \\ ${ }^{1)}$ Master Program in Mathematics, Faculty of Mathematics and Natural Sciences, \\ Padjadjaran University, Bandung \\ ${ }^{2)}$ Department of Mathematics, Faculty of Mathematics and Natural Science, \\ Padjadjaran University, Bandung \\ *Corresponding author e-mail: fadliazis16@gmail.com
}

(Article History：Received 28-01-2020; Accepted 19-04-2020; Published 20-04-2020)

\begin{abstract}
In this paper propose an EOQ mathematical model for deteriorating items. The model is developed with a demand function that decreases exponentially, a constant deterioration rate, a shortage is permitted, and a return occurs. The purpose of this model is to determine the minimum total cost by determining the optimal return time and the optimal number of orders. A numerical example is given to describe the working model. Furthermore, a sensitivity analysis was conducted to see the effect of changing parameters on the optimal solution.
\end{abstract}

Keywords: Deteriorating item, inventory, return, shortage

\section{Model Persediaan Deteriorasi Item Dengan Exponential Declining Demand dan Return}

\begin{abstract}
ABSTRAK
Dalam makalah ini mengusulkan model matematika EOQ untuk item yang mengalami deteriorasi. Model ini dikembangkan dengan fungsi permintaan yang menurun secara eksponensial, laju deteriorasi konstan, kekurangan diizinkan, dan terjadi pengembalian. Tujuan dari model ini adalah untuk menentukan biaya total minimum dengan menentukan waktu pengembalian optimal dan jumlah pesanan optimal. Contoh numerik diberikan untuk menggambarkan model bekerja. Selanjutnya, analisis sensitivitas dilakukan untuk melihat efek perubahan parameter pada solusi optimal.
\end{abstract}

Kata kunci: Deteriorasi item, persediaan, pengembalian, kekurangan

\section{INTRODUCTION}

Inventory control is very important for a company or business actor to keep industrial activities running. Inventory is an important factor for the company, because with too much inventory will cause the company to incur large costs to store goods, such as maintenance costs, warehouse rental costs, or insurance costs. Conversely, the procurement of inventories that will slightly cause losses for the company, such as the increased cost of costs, the cessation of production due to lack of raw materials or lack of products to be sold resulting in potential loss of income, and further impact is loss of consumer confidence, so that consumers look for other companies.
The complexity of inventory control will increase when the items stored are items that deteriorate (decrease in quality), such as food products, beverages, medicines, and chemicals. Careful management in storing deteriorated items is needed to improve the quality of the goods. therefore, deterioration is one of the important factors to consider in inventory management. Usually, for items that experience a deterioration factor, an agreement is reached between the supplier and the store to be able to return the damaged item under certain conditions at a certain time. This opportunity can be utilized by stores to 
minimize the costs caused by deterioration (Limansyah et al., 2018).

The inventory model with deterioration factors has been studied and developed in recent years. The problem with the value of deterioration was first discussed in 1957 by Whitin. Whitin considered and calculated the deterioration value of fashion items at the end of the specified storage period. Then, in 1963 Ghare and Schrader developed the classic EOQ model by adding a rate of deterioration in inventory and making a mathematical model for items deteriorating in inventory, Ghare and Schrader determined that the rate of deterioration was constant and the level of demand was also constant (Ouyang et al., 2005). Then developed by Covert and Philip by using the rate variable deterioration of the two parameters of Weibull and Gamma distribution to formulate a model assuming a constant demand rate and no shortages (Covert \& Philip, 1973). In 1974 Philip continued the model by considering the variable rate of deterioration from the three-parameter Weibull distribution, Shah and Jaiswal present an order-level inventory model for deteriorating items with a constant deterioration rate (Shah \& Jaiswal, 1977).

Dave and Patel developed the first deterioration inventory model with demand for linear trends and no shortages (Dave \& Patel, 1981). Dave and Patel calculate requests as a linear function of time. Then Hollier and Mak first consider exponentially decreasing demand for inventory models that obtain an optimal addition policy under constant and variable filling intervals (Hollier \& Mak, 1983). Hariga and Benkherouf generalize the Hollier and Mak model by considering demand that grows and develops exponentially (Hariga \& Benkherouf, 1994). Then, Wee developed a deterministic lot size model for deteriorating items where demand decreased exponentially during a fixed time horizon (Wee, 1995). Chung \& Tsai show that the Newton method by Wee is not suitable for first-order conditions of the total cost function (Chung \& Tsai, 1999). They change it to eliminate nonzero parts, and then apply the Newton method. Su et al. (1999) propose a production inventory model for deteriorating products with demand decreasing exponentially over the right time horizon.

An inventory model with a level of demand that is not fixed continues to be developed. Several recent works in this field have been developed by Chang \& Dye form inventory models with time-varying demand and partial backlogging (Chang \& Dye, 1999). Ouyang and Cheng developed an inventory model to decrease items with decreasing exponential demand and partial buildup. Then this model was developed by Mishra et al., (2013) with the level of demand depending on time and cost of storage that is time dependent. Shing \& Pattnayak (2013); Amutha \& Chandrasekaran (2013), and Bhanu et al., (2014) also studied inventory models for items that deteriorated. Basically, in the inventory model, the level of demand and storage costs are considered constant. But in reality, it can sometimes be observed that storage costs and demand levels depend on time.

Many studies have been carried out on inventory models for deteriorating items, but not many models have considered shortage and return factors. Setiawan et al., (2017) develop inventory models for perishable goods with supply-dependent demand, sales discount factors and consider returns. Then, Limansyah et al., (2018) developed the inventory model by considering deterioration, discount, and returns with demand that depends on the inventory referenced by the model developed by Setiawan et al. In this study, an inventory model for deterioration was developed with demand declining exponentially and considering returns and shortages.

\section{RESEARCH METHOD}

\section{Notation and Asumptions}

The mathematical model in this paper was developed by giving the following notations and assumptions.

\section{Notation:}

$I(t) \quad$ : Inventory level at time $t$

$\theta \quad$ : Deterioration rate

$D(t)$ : Demand rate $D(t)=K e^{-\lambda t}$, with $K>0$ is the initial demand and $\lambda(0<\lambda<\theta$ is a constant that regulates the rate of decline in demand

$C_{h} \quad$ : Holding cost per unit

$H C$ : Holding cost per cycle 


\begin{tabular}{|c|c|}
\hline$P$ & : Ordering cost per order \\
\hline$P_{r}$ & : Cost of one return \\
\hline$R C$ & : Return cost per cycle \\
\hline$C_{d}$ & : Deterioration cost per unit \\
\hline$C_{s}$ & : Shortage cost per unit \\
\hline$S C$ & : Shortage cost per cycle \\
\hline$t_{r}$ & : Time between orders \\
\hline$T$ & : length of each order cycle \\
\hline$M$ & $\begin{array}{l}\text { : maximum inventory level for each } \\
\text { order cycle }\end{array}$ \\
\hline$S$ & $\begin{array}{l}\text { : maximum number of shortages per } \\
\text { order cycle }\end{array}$ \\
\hline$Q$ & $\begin{array}{l}\text { : number of orders for each order } \\
\text { cycle }\end{array}$ \\
\hline
\end{tabular}

Assumptions:

1. The model is developed to inventory model one item.

2. The rate of deterioration, $\theta(0<\theta<1$ is constant, and there is no replacement or repair of items damaged during the period under consideration.

3. inventory shortages are permitted.

4. The level of demand is known and decreases exponentially.

\section{RESULTS AND DISCUSSION}

\section{Model Formulation}

The purpose of this inventory model is to determine the optimal order amount and order cycle length so as to minimize the total cost. The system behavior of the supply at any time is illustrated in Figure 1.

Inventory level

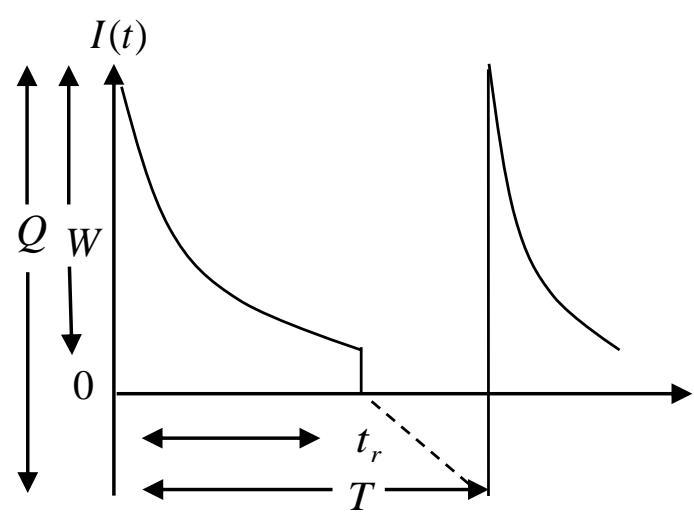

Figure 1. Inventory Level
The inventory level has decreased by the number of items requested at time $t$. At intervals $\left[0, t_{r}\right]$, the inventory level is reduced by the influence of demand and deteriorates with the rate of decline in the demand level following exponentially as shown in Figure (1). When $t=t_{r}$, the company will return all existing goods to be replaced with new items. while waiting for new items to arrive, the company can still accommodate the large amount of requests made by consumers. After that a shortage occurs at the interval $\left[t_{r}, T\right]$. From this case a differential equation can be formed as follows:

$\frac{d I(t)}{d t}+\theta I(t)=-K e^{-\lambda t}, 0 \leq t \leq t_{r}$

because when $t=t_{r}$ it is known that $I\left(t_{r}\right)=0$, then the solution from Equation (1) is obtained

$I(t)=\frac{K}{\theta-\lambda}\left[e^{t_{r}(\theta-\lambda)-\theta t}-e^{-\lambda t}\right] ; 0 \leq t \leq t_{r}$

for the maximum amount of inventory obtained by giving a boundary condition $M=I(0)$, from Equation (2) obtained

$M=I(0)=\frac{K}{\theta-\lambda}\left[e^{t_{r}(\theta-\lambda)}-1\right]$

Then, determined the amount of inventory shortages at intervals $\left[t_{r}, T\right]$

$\frac{d I(t)}{d t}=-\delta, \quad t_{r} \leq t \leq T$

with boundary condition $I\left(t_{r}\right)=0$, then the solution to the equation (4) is given by

$I(t)=\delta\left(t_{r}-t\right) ; \quad t_{r} \leq t \leq T$

then determined the maximum number of shortages per cycle as follow:

$S=-I(T)=-\delta\left(t_{r}-T\right)=\delta\left(T-t_{r}\right)$

from Equations (3) and (6), the number of orders per cycle is as follows:

$$
\begin{aligned}
Q & =M+S \\
& =\frac{K}{\theta-\lambda}\left[e^{t_{r}(\theta-\lambda)}-1\right]+\delta\left(T-t_{r}\right)
\end{aligned}
$$

After the formulation is determined for the inventory level for each order cycle at the interval $\left[0, t_{r}\right]$, the level of shortage in the interval $\left[t_{r}, T\right]$, the number of orders, the maximum number of inventories, and the number of shortage. Next, it will be formulated for total cost during the inventory period $\left[t_{r}, T\right]$. These costs include, namely: 
ordering cost, holding cost, return cost, and shortage costs.

The holding cost per cycle is

$$
\begin{aligned}
H C= & \int_{0}^{t_{r}} C_{h} I(t) d t \\
H C= & \frac{C_{h} K e^{-\lambda t_{r}}}{\lambda(\theta-\lambda)}-\frac{C_{h} K e^{-\lambda t_{r}}}{\theta(\theta-\lambda)}+\frac{C_{h} K}{\lambda(\theta-\lambda)} \\
& +\frac{C_{h} K e^{(\theta-\lambda) t_{r}}}{\theta(\theta-\lambda)}
\end{aligned}
$$

The shortage cost per cycle $\left[t_{r}, T\right]$ given by

$$
\begin{aligned}
S C & =C_{s}\left[-\int_{t_{r}}^{T} I(t) d t\right] \\
& =C_{s}\left[-\int_{t_{r}}^{T} \delta\left(t_{r}-t\right) d t\right] \\
& =C_{s}\left[\frac{1}{2} \delta\left(T^{2}-t_{r}^{2}\right)-\delta t_{r}\left(T-t_{r}\right)\right]
\end{aligned}
$$

The return cost

$$
\begin{aligned}
& R C=A_{r}+C_{s}\left[-\int_{t_{r}}^{T} \delta\left(t_{r}-t\right) d t\right] \\
& R C=A_{r}+C_{s}\left[\frac{1}{2} \delta\left(T^{2}-t_{r}{ }^{2}\right)-\delta t_{r}\left(T-t_{r}\right)\right]
\end{aligned}
$$

The total cost of inventory per unit time per silk cycle is $T I C \equiv T I C\left(t_{r}\right) . T I C=$ ordering cost $(\mathrm{OC})+$ holding cost $(\mathrm{HC})+$ shortage cost (SC) + return cost (RC). So, the total cost per unit of time is

$$
\begin{aligned}
\text { TIC } & =\frac{1}{T}\left\{P+\frac{C_{h} K e^{-\lambda t_{r}}}{\lambda(\theta-\lambda)}-\frac{C_{h} K e^{-\lambda t_{r}}}{\theta(\theta-\lambda)}+\frac{C_{h} K}{\lambda(\theta-\lambda)}\right. \\
& +\frac{C_{h} K e^{(\theta-\lambda) t_{r}}}{\theta(\theta-\lambda)}+C_{s}\left[\frac{1}{2} \delta\left(T^{2}-t_{r}^{2}\right)-\delta t_{r}\left(T-t_{r}\right)\right] \\
& +P_{r}+C_{r}\left[\frac{1}{2} \delta\left(T^{2}-t_{r}^{2}\right)-\delta t_{r}\left(T-t_{r}\right)\right]
\end{aligned}
$$

The purpose of this model is to determine the optimal value $t_{r}{ }^{*}$ to minimize the total cost per unit time (TIC). The optimal solution and calculated by determining $\quad \frac{d T I C}{d t_{r}}=0$ and $\quad$ sufficient condition $\frac{d^{2} T I C}{d t_{r}{ }^{2}}>0$

$$
\begin{aligned}
\frac{d T I C}{d t_{r}}= & \frac{-C_{h} K e^{-\lambda t_{r}}}{(\theta-\lambda) T}+\frac{\lambda C_{h} K e^{-\lambda t_{r}}}{(\theta-\lambda) \theta T} \\
& +\frac{C_{h} K e^{(\theta-\lambda) t_{r}}}{\theta T}-\frac{C_{s} \delta t_{r}}{T}-C_{s} \delta \\
& +\frac{2 C_{s} \delta t_{r}}{T}-\frac{C_{r} \delta t_{r}}{T}-C_{r} \delta \\
& +\frac{2 C_{r} \delta t_{r}}{T}=0
\end{aligned}
$$

and

$$
\begin{aligned}
\frac{d^{2} T I C}{d t_{r}^{2}} & =\frac{\lambda C_{h} K e^{-\lambda t_{r}}}{(\theta-\lambda) T}-\frac{\lambda^{2} C_{h} K e^{-\lambda t_{r}}}{(\theta-\lambda) \theta T} \\
& +\frac{(\theta-\lambda) C_{h} K e^{(\theta-\lambda) t_{r}}}{\theta T}-\frac{C_{s} \delta}{T} \\
& +\frac{2 C_{s} \delta}{T}-\frac{C_{r} \delta}{T}+\frac{2 C_{r} \delta}{T}>0
\end{aligned}
$$

Then, by using $t_{r}{ }^{*}$ which satisfies Equation (12) and (13) the optimal maximum supply level is obtained and the total inventory costs are minimum per unit time from Equations (3) and (11), each denoted by $M^{*}$ and $T I C^{*}$. Furthermore, the optimal number of orders is also denoted by $Q^{*}$ from Equation (7). Next to test the model above, numerical simulations are used by giving values to the specified parameters.

\section{Numerical Example}

In this section, a numerical example is provided to illustrate how the above model works. For illustrate the model above is given the values of the following parameters: $K=1000, \quad \lambda=0.02, \quad \theta=0.08$, $P=15, P_{r}=10, C_{s}=1.2, C_{r}=1, C_{h}=1$ , $\delta=250, T=12$.

by following the previous solution procedure, the results for the inventory model are obtained $t_{r}^{*}=4.027862460$, $M^{*}=4556.268918, \quad Q^{*}=6549.303303$, $T I C^{*}=141062.4125$.

\section{Sensitivity Analysis}

Sensitivity analysis of inventory models for deteriorating items with exponential declining demand and returns performed on the value of $\lambda$ and $\theta$ to see changes in the values of $t_{r}^{*}, M^{*}, Q^{*}$ and $T I C^{*}$. Sensitivity 
analysis with different parameters is shown in the following table:

Tabel 1. Sensitivity Analysis for parameter $\lambda$

\begin{tabular}{clccc}
\hline $\begin{array}{c}\text { Change } \\
(\boldsymbol{\%})\end{array}$ & $t_{r}{ }^{*}$ & $Q^{*}$ & $M^{*}$ & $T I C^{*}$ \\
\hline+50 & 4.132 & 6557.6 & 4590.89 & 11326 \\
& 8827 & 7818 & 886 & 4.8320 \\
+25 & 4.079 & 6553.5 & 4573.45 & 12337 \\
& 54216 & 6960 & 514 & 5.8619 \\
& & & & \\
0 & 4.027 & 6549.3 & 4556.26 & 14106 \\
& 86246 & 0330 & 891 & 2.4125 \\
-25 & 3.977 & 6544.8 & 4539.33 & 17312 \\
& 76505 & 9758 & 884 & 3.2497 \\
& & & & \\
-50 & 3.929 & 6540.3 & 4522.66 & 24028 \\
& 17609 & 6883 & 285 & 7.6528 \\
& & & & \\
\hline
\end{tabular}

Tabel 2. Sensitivity Analysis for parameter $\theta$

\begin{tabular}{clccl}
\hline $\begin{array}{c}\text { Change } \\
(\%)\end{array}$ & $t_{r}{ }^{*}$ & $Q^{*}$ & $M^{*}$ & $T I C^{*}$ \\
\hline+50 & 3.824 & 6702.9 & 4659.18 & 85545. \\
& 81844 & 7798 & 260 & 48967 \\
+25 & 3.923 & 6628.2 & 4609.15 & 10635 \\
& 56457 & 6573 & 687 & 9.8993 \\
& & & & \\
0 & 4.027 & 6549.3 & 4556.26 & 14106 \\
& 86246 & 0330 & 891 & 2.4125 \\
-25 & 4.138 & 6465.7 & 4500.30 & 21048 \\
& 11657 & 7248 & 162 & 6.3184 \\
-50 & 4.254 & 6377.3 & 4441.02 & 41879 \\
& 75049 & 3787 & 550 & 8.2382 \\
\hline
\end{tabular}

From Tables 1 and 2, points can be discussed as follows:

1. Table 1 indicates that, when the parameter $\lambda$ increases, then $t_{r}^{*}, Q^{*}, M^{*}$ increases, while $T I C^{*}$ has decrease. From Table 1 it can be seen that $t_{r}^{*}, Q^{*}, M^{*}, T I C^{*}$ are moderatly sensitive to changes in parameter $\lambda$.

2. Table 2 indicates that, when the parameter $\theta$ has increased, then $Q^{*}$ and $M^{*}$ also increased, while $t_{r}^{*}$ and $T I C^{*}$ has decreased. From Table 2 it can be seen that $t_{r}^{*}, Q^{*}, M^{*}, T I C^{*}$ are sensitive to changes in parameter $\theta$.

\section{CONCLUSIONS}

In the inventory model for deteriorating items with exponential declining demand and return factors, the rate of deterioration and the rate of demand greatly affect the optimal solution of the model. When the demand rate $(\lambda)$ increases, then $t_{r}$ gets longer, $Q$ and $M$ increases, and TIC decreases. This is caused by fewer requests, causing longer returns, $q$ and $m$ increasing, and tic getting smaller, because the cost of returns and costs of shortages is getting smaller. When the deterioration rate $(\theta)$ increases, $Q$ and $M$ also increases, but $t_{r}$ and TIC decreased. This is due to the large value $\theta$ which causes the return time to be shorter so that the holding costs are small which results in the total cost being small.

\section{REFERENCES}

Amutha, R. \& E. Chandrasekaran. 2013. An EOQ Model for a Deteriorating Item With Quadratic Demand and Time Depandent Holding Cost. International Journal of Emerging Science and Engineering, 5: 5-6.

Bhanu, P.D., S. Trailokyanath \& P. Hadhibandu. 2014. An Inventory Model for Deteriorating Items With Exponential Declining Demand and Time- Vaying Holding Cost. American Journal of Operations Research, 4: 1-7.

Chang, H. J. \& C.Y. Dye. 1999. An EOQ Model With Deteriorating ItemsWith Time Varying Demand and Partial Backlogging. Journal of the Operational Research Society, 50: 1176-1182.

Chung, H. J. \& S.F. Tsai. 1999. A solution procedure to determine inventory replenisment policies for deteriorating items in a declining market: Journal of information \& Optimization Science, 20: $1-15$.

Covert, R.B. \& G.S. Philip. 1973. An EOQ model with Weibull distribution deterioration. AIIE Transactions, 5: 323-326. 
Dave \& L.K. Patel. 1981. (T, Si) Policy Inventory Model for Deteriorating Items with Time Proportional Demand. Journal of the Operational Research Society, 32: 137-142.

Hariga M. \& L. Benkherouf. 1994. Optimal and heuristic replenisment model for deteriorating items with exponential time varying demand. Europan Journal of Operational Research, 79: 123-137.

Hollier, R.H. \& K.L. Mak. 1983. Inventory reflenisment policies for deteriorating items in a declining market. Internatioanl Journal of Production Research, 21: 813-826.

Limansyah, T., J.D. Lesmono \& N. Loedy. 2018. Development of inventory models with deterioration, discount and return factors. Bandung : Institute for Research and Community Service at Parahyangan Catholic University.

Mishra, V. K., L.S. Singh \& R. Kumar. 2013. An Inventory Model for Deteriorating Items with Time-Dependent Demand and Time-Varying Holding Cost under Partial Backlogging. Journal of Industrial Engineering International, 9(4): 1-5.

Ouyang, L.Y., K.S. Wu \& M.C. Cheng. 2005. An Inventory Model for Deteriorating Items With Exponential Declining Demand and Partial Backlogging. Yugoslav Journal of Operations Research, 15(2): 277-288.
Setiawan, S.W. D. Lesmono \& T. Limansyah. 2017. A Perishable Inventory Model wit Return. Paper presented at the $2^{\text {nd }}$ Internatioanl Conference on Mathematics, Science, Education and Technology, Padang, October 5-6, 2017.

Shah, Y.K. \& Jaiswal. 1977. An order level inventory model for a system with constant rate of deterioration. Opsearch, 14: 74-184.

Singh, T. \& N. Pattnayak. 2013. An EOQ Model for Deteriorating Items With Linear Demand, Variable Deterioration and Partial Backlogging. Journal of Service Science and Management, 6: 186-190.

Su, CT., C.W. Lin \& C.H. Tsai. 1999. A deterministic production inventory model for deteriorating items with an exponential declining demand. Operational Research Society of India, 36: 95-106.

Wee, H. M. 1995. A deterministic Lot-Size Inventory Model for Deteriorating Items with Shortages and a Declining Market. Computers and Operations Research, 22(3): 345-356. 